\title{
Toxicity of Organophosphorus Insecticides in the Zebra Mussel, Dreissena polymorpha $\mathbf{P}$.
}

\author{
C. Dauberschmidt, D. R. Dietrich*, C. Schlatter \\ Institute of Toxicology, Federal Institute of Technology and University of Zürich, Schorenstrasse 16, CH-8603 Schwerzenbach, Switzerland
}

\begin{abstract}
The 96-h toxicity of four organophosphates (thiometon, disulfoton, malathion, and demeton-S-methyl, the oxygen analogue of thiometon) in the freshwater bivalve mollusc Dreissena polymorpha was tested using different nominal concentrations ranging between 6 and $50 \mathrm{mg} / \mathrm{L}$. No mortalities were observed in mussels exposed to malathion and demeton$S$-methyl (26 mg/L and $6 \mathrm{mg} / \mathrm{L}$, respectively), and at the lowest concentrations of thiometon and disulfoton $(6$ and $10 \mathrm{mg} / \mathrm{L}$, respectively). At higher thiometon and disulfoton concentrations, mortalities occurred. At the highest concentrations of 50 $\mathrm{mg}$ thiometon/L and $30 \mathrm{mg}$ disulfoton/L, mussel mortalities of 88 and $93 \%$, respectively, were determined. Organophosphate concentrations of up to a factor 10 times higher than in the ambient water were found in exposed mussels, irrespective of whether they were alive or dead. The search for organophosphate metabolites via GC/MS analysis of mussel tissue extracts was negative, suggesting lacking or low oxidative activation of the insecticides used. The mollusc is highly resistant to toxic effects of organophosphate insecticides and their biological active oxygen analogues.
\end{abstract}

On November 1, 1986, a pesticide storing facility at Sandoz in Basel (Switzerland) caught fire. In order to extinguish the fire, water was pumped at high volumes from the nearby river Rhine. This water found its way back into the river Rhine due to overflowing sewage canals (Capel et al. 1988; Güttinger and Stumm 1992). Along with the fire-extinguishing water, pesticides stored in the affected facility were swept into the river. Among these pesticides were organophosphate insecticides, mainly thiometon and disulfoton, mercurial-based fungicides, and herbicides. Consequently, the river Rhine ecosystem

* Present address: Department of Environmental and Occupational Health, University of Pittsburgh, Pittsburgh, PA 15238, USA

Correspondence to: C. Dauberschmidt faced high water concentrations of these pesticides. Measured peak concentrations close to the source of contamination were $500 \mu \mathrm{g} / \mathrm{L}$ and $600 \mu \mathrm{g} / \mathrm{L}$ for thiometon and disulfoton, respectively. These pesticide concentrations severely affected insect, crustacean, and fish populations of the Rhine ecosystem. In particular, eels (Anguilla anguilla L.) appeared to be highly susceptible to organophosphate intoxication, as fish of this species were found dead up to $400 \mathrm{~km}$ downstream of the source of contamination (Güttinger and Stumm 1992).

Based on the chemical characteristics of these compounds, it was assumed they would undergo quick hydrolysis and biodegradation, and would not remain in the Rhine sediments (EAWAG 1987). However, up to $31 / 2$ months following the incident, copious concentrations of unhydrolyzed parent compound of the major contaminants, thiometon and disulfoton, were found in the Rhine river sediment near the site of original contamination (430 ppm and 3,000 ppm, respectively, Institute of Toxicology, unpublished data).

In addition to the initial fish deaths, unusually high numbers of dead diving ducks, namely tufted duck (Aythya fuligula) and pochard (Aythya ferina), were found around the site of maximal water and sediment contamination up to four months after the incident. As zebra mussels (Dreissena polymorpha P.) represent the predominant part of the diet of these birds (Suter 1982), mussels from this part of the Rhine were inspected for viability and organophosphate contamination. Surprisingly, they presented no obvious signs of intoxication despite the high organophosphate concentrations determined in the surrounding sediment. Furthermore, unexpected high tissue concentrations of unhydrolyzed thiometon (up to $20 \mathrm{mg} / \mathrm{kg}$ ) and disulfoton (up to $300 \mathrm{mg} / \mathrm{kg}$ ) were found in the Dreissena polymorpha analyzed (Institute of Toxicology, unpublished data). Based on the high transformation rate of organophosphates in vertebrates, it had been assumed that accumulation of organophosphorus pesticides by aquatic organisms was not likely to occur (De Bruijn and Hermens 1991). The causal relationship between the observed death of diving ducks and the fire incident demonstrates that this is not true for Dreissena. Because zebra mussels represent an important component of the aquatic food chain, it was important to investigate the basis for the accumulation of highly 
Table 1. Amounts of organophosphates added once every $24 \mathrm{~h}$ for a total of 4 times, resulting average water concentrations, mortalities, and tissue concentrations in dead and surviving Dreissena polymorpha at the end of the $96 \mathrm{~h}$ experiments: Exposures to thiometon and disulfoton, the spilled chemicals at Sandoz, and exposures to malathion and demeton-S-methyl

\begin{tabular}{|c|c|c|c|c|}
\hline \multirow{2}{*}{$\begin{array}{l}\text { Added } \\
\text { amounts }\end{array}$} & \multirow{2}{*}{$\begin{array}{l}\text { Average water } \\
\text { concentrations }\end{array}$} & \multirow{2}{*}{$\begin{array}{l}\text { 96-h } \\
\text { mortality }\end{array}$} & \multicolumn{2}{|c|}{ Tissue concentrations after $96 \mathrm{~h}$ exposure } \\
\hline & & & Dead mussels & Live mussels \\
\hline \multicolumn{5}{|c|}{ Thiometon } \\
\hline $6 \mathrm{mg} / \mathrm{L}$ & $2.7 \mathrm{mg} / \mathrm{L}$ & $0 \%$ & - & $63 \mathrm{mg} / \mathrm{kg}$ \\
\hline $12 \mathrm{mg} / \mathrm{L}$ & $4.6 \mathrm{mg} / \mathrm{L}$ & $39 \%$ & $59 \mathrm{mg} / \mathrm{kg}$ & $50 \mathrm{mg} / \mathrm{kg}$ \\
\hline $16 \mathrm{mg} / \mathrm{L}$ & $5.8 \mathrm{mg} / \mathrm{L}$ & $44 \%$ & $42 \mathrm{mg} / \mathrm{kg}$ & $66 \mathrm{mg} / \mathrm{kg}$ \\
\hline $25 \mathrm{mg} / \mathrm{L}$ & $9.0 \mathrm{mg} / \mathrm{L}$ & $63 \%$ & $44 \mathrm{mg} / \mathrm{kg}$ & $83 \mathrm{mg} / \mathrm{kg}$ \\
\hline $50 \mathrm{mg} / \mathrm{L}$ & $12.9 \mathrm{mg} / \mathrm{L}$ & $88 \%$ & $96 \mathrm{mg} / \mathrm{kg}$ & $128 \mathrm{mg} / \mathrm{kg}$ \\
\hline \multicolumn{5}{|c|}{$\begin{array}{l}\text { Disulfoton } \\
10 \mathrm{mg} / \mathrm{L}\end{array}$} \\
\hline $10 \mathrm{mg} / \mathrm{L}$ & $1.8 \mathrm{mg} / \mathrm{L}$ & $0 \%$ & - & $30 \mathrm{mg} / \mathrm{kg}$ \\
\hline $15 \mathrm{mg} / \mathrm{L}$ & $2.1 \mathrm{mg} / \mathrm{L}$ & $13 \%$ & $51 \mathrm{mg} / \mathrm{kg}$ & $72 \mathrm{mg} / \mathrm{kg}$ \\
\hline $24 \mathrm{mg} / \mathrm{L}$ & $2.2 \mathrm{mg} / \mathrm{L}$ & $31 \%$ & $55 \mathrm{mg} / \mathrm{kg}$ & $73 \mathrm{mg} / \mathrm{kg}$ \\
\hline $26 \mathrm{mg} / \mathrm{L}$ & $2.3 \mathrm{mg} / \mathrm{L}$ & $80 \%$ & $73 \mathrm{mg} / \mathrm{kg}$ & $113 \mathrm{mg} / \mathrm{kg}$ \\
\hline $30 \mathrm{mg} / \mathrm{L}$ & $3.7 \mathrm{mg} / \mathrm{L}$ & $93 \%$ & $83 \mathrm{mg} / \mathrm{kg}$ & $106 \mathrm{mg} / \mathrm{kg}$ \\
\hline \multicolumn{5}{|c|}{$\begin{array}{l}\text { Malathion } \\
10 \mathrm{mg} / \mathrm{L}\end{array}$} \\
\hline $10 \mathrm{mg} / \mathrm{L}$ & $2.7 \mathrm{mg} / \mathrm{L}$ & $0 \%$ & - & $2 \mathrm{mg} / \mathrm{kg}$ \\
\hline \multirow{2}{*}{\multicolumn{5}{|c|}{$\begin{array}{l}\text { Demeton-S-methyl } \\
6 \mathrm{mg} / \mathrm{L}\end{array}$}} \\
\hline & & & & \\
\hline \multirow{2}{*}{\multicolumn{5}{|c|}{ Control }} \\
\hline & $0.0 \mathrm{mg} / \mathrm{L}$ & $0 \%$ & & \\
\hline
\end{tabular}

toxic compounds in this mollusc which may lead to a potential hazard for higher trophic levels.

The goal of this study was to demonstrate the high resistance of Dreissena towards organophosphates in laboratory experiments, to see whether mussels retain organophosphates without showing signs of intoxication, to determine metabolites of thiometon and disulfoton, and to try to elucidate the basis of the resistance observed in the field.

\section{Materials and Methods}

\section{Exposure of Dreissena polymorpha in the Laboratory}

Zebra mussels (Dreissena polymorpha) were collected at an average depth of $5 \mathrm{~m}$ from Lake Zurich by scuba diving. Thereafter, they were kept in a flow-through aquarium with dechlorinated tap water (average hardness $4.8 \mathrm{meq} / \mathrm{L}$ ) for a few weeks to several months. The water temperature ranged between $12^{\circ}$ and $18^{\circ} \mathrm{C}$. Dreissena were fed twice a week with fresh plankton during the summer months and with commercially available, dried Spirulina platensis and Chlorella pyrenoidosa cultures during winter months as described by Nichols (1992).

In the first series of experiments, Dreissena were exposed to high thiometon and disulfoton concentrations, the two organophosphates mainly spilled at the Sandoz incident (Table 1). Mussels collected in July were exposed during the months of August to December. The experimental set-up allowed the investigators to run a thiometon, a disulfoton, and a control exposure simultaneously ( 3 aquaria). Three days before the $96 \mathrm{~h}$ exposure experiments were started, 40 mussels (valve length $1.6-2.3 \mathrm{~cm}$ ) were placed into each glass aquaria $(7.5 \mathrm{~L}$ dechlorinated tap water continuously recirculated). The mussels were acclimatized slowly to the test water temperature of $18 \pm 1^{\circ} \mathrm{C}$ and $\mathrm{pH}$ 8.5. During this acclimatization phase, as well as during the experiments, the mussels were not fed. The tests were carried out by adding the respective amount of the different organophosphates to the aquaria once every $24 \mathrm{~h}$ during a total period of $96 \mathrm{~h}$ (Table 1). Evaporation of water and/or test compound was prevented by covering the aquaria.
Dead mussels were removed daily, and stored at $-20^{\circ} \mathrm{C}$ until further processing. The shell-closing reflex served as a parameter for mussel viability. Mussels lacking this reflex were considered dead. For comparison to a different organophosphate, Dreissena were exposed to malathion in two additional experiments. The amounts of malathion added corresponded to the 10 and $26 \mathrm{mg} / \mathrm{L} / \mathrm{d}$ disulfoton experiment. Finally, Dreissena were exposed to the potent oxygen analogue of thiometon, demeton-S-methyl, at the lowest concentration used for thiometon (Ta-
ble 1).

\section{Chemicals}

The test chemicals used in the experiments were thiometon, disulfoton, demeton-S-methyl, and malathion. Thiometon $(O, O$-dimethyl- $S$-[2ethylmercaptoethyl]-phosphorodithioate, purity $53.1 \%$ ), the solvent ShellSol ${ }^{\circledR}$, and disulfoton $(O, O$-diethyl-S-[2-ethylmercaptoethyl]phosphorodithioate, 92.3\%) were a gift from Sandoz Agro, Basel, $S$ witzerland. Demeton-S-methyl (the oxygen analogue of thiometon, purity $95.2 \%$ ) and malathion $(98.5 \%)$ and the reference compound disulfoton sulfoxide (10 ng/ $\mu \mathrm{l}$ in toluene) were obtained from $\mathrm{Dr}$. Ehrenstorfer $\mathrm{GmbH}$, Augsburg, FRG. For direct comparison with thiometon, demeton- $S$-methyl was diluted with the solvent ShellSol to the same concentration as thiometon $(53.1 \%)$. To obtain the sulfone/ sulfoxide analogues, parent thiometon and disulfoton were oxidized with potassium permanganate as described in Wisson et al. (1976).

Analytical grade $n$-hexane, petroleum benzene, dichlormethane, and sodium sulphate anhydrous (extra pure) were purchased from Merck ABS. Florisil (PR ${ }^{\oplus}, 60-100$ mesh) was obtained from Fluka.

\section{Water Analysis}

Water samples $(10 \mathrm{ml})$ were taken $10 \mathrm{~min}$ after addition of the organophosphate and $24 \mathrm{~h}$ thereafter to monitor organophosphate concentrations. These samples were extracted three times with $10 \mathrm{ml}$ of petroleum benzene. Petroleum benzene extracts were evaporated in vacuo to dryness. The residue was then taken up in $1 \mathrm{ml} n$-hexane. 
Percent recovery of the organophosphates from water samples were determined by adding $100 \mu \mathrm{l}$ of the respective standard (100 ppm) to $10 \mathrm{ml}$ tap water. These spiked samples were extracted using the method described above. A recovery of $68 \pm 13 \%(n=3), 92 \pm 6 \%(n=3)$, $53 \pm 1 \%(n=2)$, and $89 \pm 4 \%(n=2)$ was determined for thiometon, disulfoton, demeton- $S$-methyl, and malathion, respectively.

The average water concentration during the experiment was calculated by dividing the area under the curve by the exposure time.

\section{Extraction of Organophosphates in Mussel Tissue}

The mussels were thawed, shucked, and the excess water drained off before the tissue was weighed and dissected. The ensuing tissue extraction followed the protocol for determination of organophosphate pesticides published by the DFG (1982). Pooled tissue of 5 mussels was ground with six times its weight of anhydrous sodium sulphate with a mortar until homogeneous. The homogenate was extracted under reflux three times for $10 \mathrm{~min}$ with $50 \mathrm{ml}$ petroleum benzene. The petroleum benzene extracts were evaporated in vacuo to dryness. The residue was taken up in $1 \mathrm{ml} n$-hexane.

For the tissue extracts of mussels exposed to thiometon and disulfoton, a clean-up procedure was introduced prior to GC analysis. A column was filled with 5.0 g Florisi $l^{\circledR}$ (deactivated with $20 \%$ water) swelled in petroleum benzene. The mussel extract was placed onto the column and eluted with $60 \mathrm{ml}$ of petroleum benzene/dichlormethane mixture $(8: 2, v / v)$. The eluate was concentrated with a rotary evaporator and dissolved in $1 \mathrm{ml} n$-hexane. Since experience had shown that it was possible to achieve reproducible and reliable analytical results with direct injection of the residues dissolved in $n$-hexane, the cleanup step was left out for the extracts of demeton- $S$-methyl and malathionexposed mussels.

The reliability of the tissue extraction and clean-up method was tested by determining the recovery of the organophosphate compound. This was done by adding a known amount of the respective organophosphate standard to untreated mussel tissue and by running these spiked samples through the extraction and clean-up method as described above. The recovery was expressed as \% of the added amount. A recovery of $55 \pm 6 \%(n=3)$ and $86 \pm 6 \%(n=3)$ was determined for thiometon and disulfoton, respectively, while recoveries of $92 \pm 4 \%$ $(n=2)$ and $100 \pm 7 \%(n=2)$ were determined for demeton- $S$-methyl and malathion.

\section{Gas Chromatography}

The analysis of both the water and tissue samples was carried out with a Carlo Erba HRGC gas chromatograph (GC) equipped with a split/ splitless injector and a nitrogen phosphorus detector (NPD). Separation was performed on $20 \mathrm{~m} \times 0.30 \mathrm{~mm}$ glass capillary columns coated with $0.25 \mu \mathrm{m}$ PS086 (polysiloxane containing $86 \%$ methyl and $14 \%$ phenyl) in the case of thiometon and disulfoton, and $0.15 \mu \mathrm{m}$ OV-31$\mathrm{OH}$ (polysiloxane containing $83 \%$ methyl and 17\% 3-cyanopropyl) in the case of demeton- $S$-methyl and malathion. The carrier gas was hydrogen at a pressure of $40 \mathrm{kPa}$ (linear velocity $0.5 \mathrm{~ms}^{-1}$ ). The temperature of the injector and detector was $280^{\circ} \mathrm{C}$. One $\mu$ l of the sample dissolved in $n$-hexane was injected at a split ratio of $1: 10$. For thiometon and disulfoton samples, the temperature was programmed to increase from $150^{\circ} \mathrm{C}$ (hold time $2 \mathrm{~min}$ ) up to $240^{\circ} \mathrm{C}$ at a rate of $10^{\circ} \mathrm{C} / \mathrm{min}$. For the analysis of demeton- $S$-methyl and malathion, the temperature was held at $200^{\circ} \mathrm{C}$ and $230^{\circ} \mathrm{C}$, respectively (isothermal analysis). For quantification, reference compunds dissolved in $n$-hexane were employed. The NPD signals were recorded and integrated using a Spectra-Physics SP 4290 integrator. Concentrations of the respective organophosphates were determined by integrating the area of the organophosphate specific peak and using a standard curve.

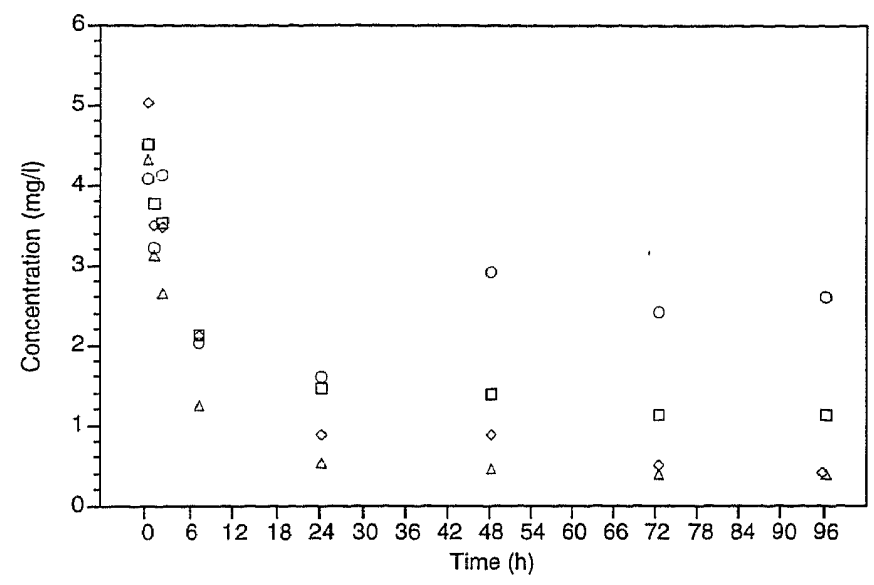

Fig. 1. Organophosphate concentrations ( $\mathrm{mg} / \mathrm{L}$ ) in the glass aquaria without zebra mussels following a single addition of $10 \mathrm{mg} / \mathrm{L}$ thiometon $\square$, disulfoton $\Delta$, malathion $\diamond$, and demeton-S-methyl $\circ$, respectively $\left(t_{0}=\right.$ first measurement, 10 min after addition)

\section{Metabolites}

In order to answer the question whether organophosphates are activated either to more toxic metabolites, as demonstrated in mammals (Gallo and Lawryk 1991), or to non-toxic metabolites, tissue samples of exposed mussels were analyzed for metabolites. To ensure extraction of the slightly more polar metabolites, acetonitrile was used instead of petroleum benzene. The aliquots of extracts were analyzed by gas chromatography/mass spectrometry (GC/MS) without previous purification. The analysis was made with a Finnigan 4500 mass spectrometer. Separation was performed under the same conditions as the other thiometon and disulfoton samples. The temperature was programmed to increase from $60^{\circ} \mathrm{C}$ (hold time $1 \mathrm{~min}$ ) up to $200^{\circ} \mathrm{C}$ at a rate of $20^{\circ} \mathrm{Cl}$ min, and then up to $280^{\circ} \mathrm{C}$ at a rate of $5^{\circ} \mathrm{C} / \mathrm{min}$.

\section{Results}

The stability of the organophosphate compounds in water without zebra mussels was monitored for $96 \mathrm{~h}$ after one single addition of $10 \mathrm{mg} / \mathrm{L}$ of the respective compounds. Concentrations decreased rapidly for thiometon and especially for disulfoton and malathion, whereas demeton- $S$-methyl, the oxygen analogue of thiometon, seemed to be more stable in water (Figure 1). Figure 2 depicts the time-courses of thiometon and disulfoton following addition of the respective compound every $24 \mathrm{~h}$ to the experimental units containing zebra mussels.

Control zebra mussels remained in a clustered array following introduction into the glass aquaria, maintained a quick valve closing reflex throughout the experimental period, produced byssus threads for attachment to the glass, and filtered actively. In contrast, zebra mussels exposed to thiometon and disulfoton at concentrations which induced mortality filtered only sporadically or remained closed. Inexistent or decreased production of byssus threads was observed and in addition, depending on the concentration level used, byssus threads were rejected. This resulted in a single organism array of the normally clustered zebra mussels. Following exposure to high concentrations, mussels presented with widely opened valves and demonstrated a delayed closing reflex and enhanced mucus production. 

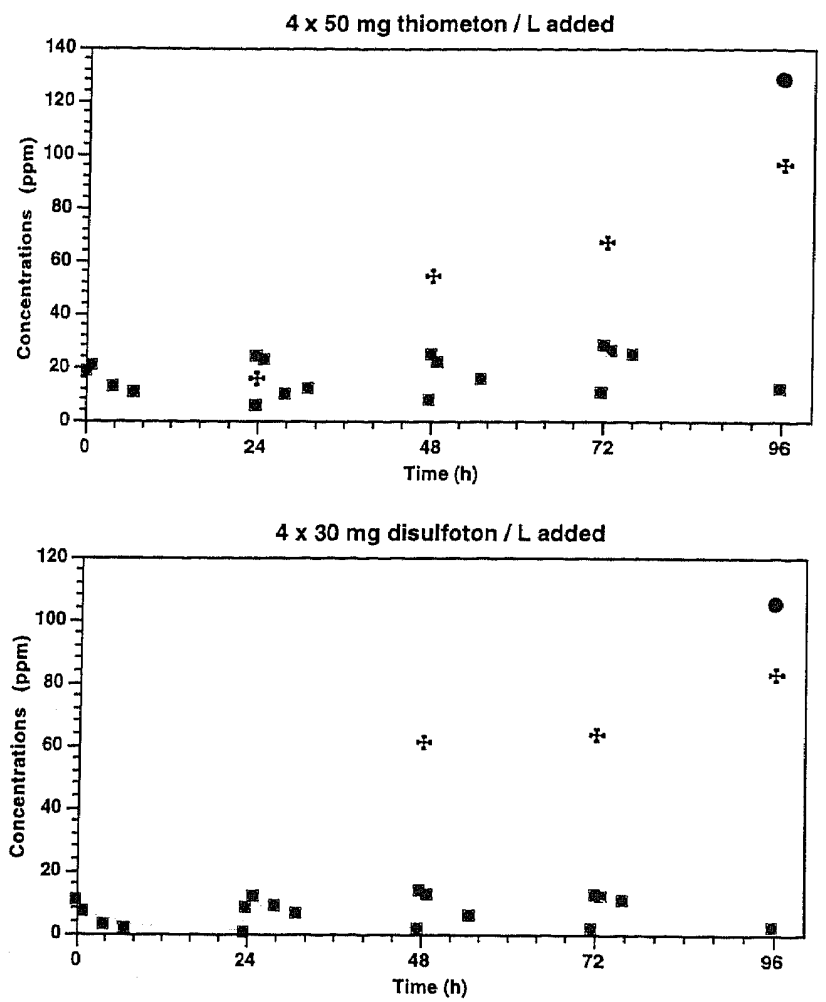

Fig. 2. Organophosphate concentrations in water ( $(\mathbf{1})$ and tissue of dead $(*)$ and live $(\bullet)$ Dreissena polymorpha exposed to $50 \mathrm{mg}$ thiometon and, respectively, $30 \mathrm{mg}$ disulfoton/L/d for $96 \mathrm{~h}$ (single analysis of water or pooled tissue of 5 mussels)

Mortality increased with exposure concentration (Table 1) and exposure time. The higher the concentration, the earlier the appearance of dead mussels. At similar water concentrations, thiometon induced higher mortality than disulfoton. No mortality could be observed in the experiment with the oxygen analogue of thiometon, demeton- $S$-methyl. Malathion induced no mortality, even at water concentrations higher than lethal disulfoton concentrations.

Zebra mussel tissue concentrations increased with exposure time. A plateau concentration was not reached within the $96 \mathrm{~h}$ of exposure (Figure 2). The highest tissue concentrations were always found in mussels still alive after $96 \mathrm{~h}$ of exposure, i.e., $128 \mathrm{mg}$ thiometon and $106 \mathrm{mg}$ disulfoton $/ \mathrm{kg}$ tissue. Lower concentrations were found in mussels dying before the end of the $96 \mathrm{~h}$ experiment. Exposure to malathion or demeton- $S$ methyl resulted in much lower tissue concentrations than those found for similar ambient water concentrations of thiometon and disulfoton (Table 1).

In the GC/MS analysis, no signals of the typical fragment ions of thiometon and disulfoton metabolites (sulfoxides, sulfones, and oxygen analogues) known from the literature (Yashiki et al. 1990) were observed (detection limit $0.5 \mathrm{ng}$ ). The concentration-ratio of the parent compound to the potentially existing metabolites was greater than 25 .

\section{Discussion}

A major problem in static aquatic toxicity tests is that, in some cases, the active ingredient rapidly disappears. Stable water concentrations were not attained with any of the organophosphates tested in our studies. Similar observations were made by other authors (Miller et al. 1966; Takase and Oyama 1985; Wanner et al. 1989; Frank et al. 1991). The short half-lives in the water are most likely due to hydrolysis and adsorption to the glass walls of the aquaria, silicon adhesive (ASTM 1990), and to the pump. Takase and Oyama (1985) calculated for disulfoton a half-life in water of $16 \mathrm{~h}$ at $25^{\circ} \mathrm{C}$ and aeration, whereas thiometon and disulfoton degraded much more slowly when stirred at $10^{\circ} \mathrm{C}$, with half-lives of 5 and 7 days, respectively (Wanner et al. 1989). This demonstrates that the disappearance of thiometon and disulfoton is dependent on recirculation, temperature, and aeration. Following oxidation, organophosphates appear to be more stable in water. This is demonstrated by the higher persistence of demeton-S-methyl in this study (Figure 1) as well as of the disulfoton oxygen analogue (Yashiki et al. 1990).

The low sensitivity of Dreissena observed in the field situation towards organophosphates could be confirmed with the first series of experiments. Exposure to concentrations 10 -fold the one in the Rhine water immediately after the spill had no effects on the mussels within $96 \mathrm{~h}$. Mortality occurred only at more than 20 -fold the measured Rhine water concentrations (12 mg thiometon/L, $15 \mathrm{mg}$ disulfoton/L, Table 1). For disulfoton, $96 \mathrm{~h} \mathrm{LC}$ 50 are known also for other aquatic species, i.e., rainbow trout $1.85 \mathrm{mg} / \mathrm{L}$, stonefly $5 \mu \mathrm{g} / \mathrm{L}$ (Mayer and Ellersieck 1986) and eel $37 \mu \mathrm{g} / \mathrm{L}$ (Arnold and Braunbeck 1992). However, it is difficult to compare the latter data with the ones obtained in the study presented as the methods of exposure, i.e., static (rainbow trout and stonefly data) vs. continuous flow-through (eel data) vs. recirculation and dose renewal (data from this study), are completely different. In order to roughly compare our results with literature data, the average measured concentrations of the experiments were used. Thus, an approximately average disulfoton water concentration of $2.2 \mathrm{mg} / \mathrm{L}$ induced $50 \%$ mortality in the zebra mussel within $96 \mathrm{~h}$. When compared to the eel, Dreissena polymorpha is 60 times less susceptible to disulfoton than the eel. As only nominal concentrations were given in the static test for the determination of disulfoton toxicity in rainbow trout, the $96 \mathrm{~h} \mathrm{LC}_{50}$ of $1.85 \mathrm{mg} / \mathrm{L}$ reported by Mayer and Ellersieck (1986) is questionably high and can neither be compared directly to the eel nor to the data of this study.

Taking into account the tissue concentrations for thiometon and disulfoton (Table 1), the question arises whether the observed mortality in Dreissena was a result of the $96 \mathrm{~h}$ exposure to a mean concentration of organophosphates, or whether the mortality was induced by the repeated peak concentrations the mussels were exposed to every $24 \mathrm{~h}$. Indeed, the minute differences in the average concentrations between the different exposures alone seem unlikely to have induced the observed differences in mortality (Table 1). The data suggest that the repeated concentration peaks (Figure 2) rather than the average effective water concentrations were responsible for the observed toxicity in the mussels. It is probable that Dreissena could survive even higher average concentrations than the ones used in the experiments presented here, if the mode of application would be continuous rather than intermittent ( $24 \mathrm{~h}$ intervals).

The higher resistance of Dreissena towards organophosphates compared to other animal species seems to be even more distinct in the case of malathion. Mammals and aquatic species demonstrate a higher sensitivity to malathion (e.g., $96 \mathrm{~h} \mathrm{LC}_{50}$ rainbow trout in static tests $4-200 \mu \mathrm{g} / \mathrm{L}$; Mayer and Ellersieck 1986) 
than to disulfoton and thiometon, whereas in our study the measured average water concentration of $4.7 \mathrm{mg} / \mathrm{L}$ produced no mortality in Dreissena polymorpha.

In mammals, thiophosphate insecticides are metabolically oxidized. Due to their better binding and thus stronger inhibition of cholinesterases, they then become 3- to 4-fold more toxic than the respective parent compound (Gallo and Lawryk 1991). The fact that thiometon and disulfoton metabolites (oxygen analogues, sulfoxides, sulfones) were not detected in the tissue of exposed mussels in this study indicates that organophosphates are not metabolized by Dreissena at all or at least very slowly. Indeed, lacking or slow metabolism of xenobiotics in general has been reported repeatedly in aquatic molluscs (Payne et al. 1987). However, the fact that no metabolites were detected is not a sure indication that they are not produced. In mammals, it has been shown that in plasma, active oxygen analogues are present at levels 30-100 times below parent compound concentrations (Willems et al. 1993). Because of the detection limit in this study of $0.5 \mathrm{ng}$, potentially existing metabolites would have been detected only if they were present at levels 25 times below parent compound concentrations.

Nevertheless, a possible missing oxidative metabolism in the mussels does not a priori explain the observed resistance of the zebra mussels toward these insecticides. Dreissena proved to be highly resistant not only to the parent compound thiometon, but also towards demeton- $S$-methyl. This might indicate that this acetylcholinesterase inhibitor, potent in mammals, either does not interact with the mussel cholinesterases, or that an interaction does not necessarily lead to severe toxic effects. Even though acetylcholine serves as a neurotransmitter in zebra mussels (Rosza 1984), the importance of acetylcholine as well as its esterases in neurotransmission processes in molluscs has not been clearly elucidated (Heyer et al. 1973; Mercer and McGregor 1982).

The biological effects of cholinesterase-inhibiting compounds in zebra mussels might well be due to effects other than inhibition of acetylcholinesterase. It can be hypothesized that less specific adducts with enzymes or proteins other than cholinesterase could occur. These adducts could be responsible for the observed accumulation and possibly also for the mortality at high doses. Specific as well as unspecific binding of organophosphates to proteins other than cholinesterases has been reported earlier. For instance, the enzyme neuropathy target esterase is inhibited by organophosphates due to phosphorylation of a hydroxyl residue of serine at the catalytic centre, similarly to the binding to serine of acetylcholine (Johnson 1975; Lotti 1992). There is evidence that organophosphates attack serine residue-containing active sites of other enzymes (Mahendru and Agarwal 1983) or receptors (Ward et al. 1993). Organophosphate binding to various enzymes or proteins in blood serum was also reported by Singh et al. (1985).

Organophosphorus pesticides were also shown to have strong inhibitory effects on aerobic metabolism and phosphatase activity in snail (Mahendru and Agarwal 1983). Abnormal head regeneration of planaria (Villar et al. 1994) and damaged membranes in mammals (Gallo and Lawryk 1991; Prozorovskii and Skopichev 1993) were shown as well.

It has been demonstrated that bioconcentration of organophosphates in mussels (Miller et al. 1966; McLeese et al. 1979; Ferrario et al. 1994) is compound-specific as in other aquatic animals such as amphibians (Hall and Kolbe 1980) and fish (De Bruijn and Hermens 1991). Relative to the effective water concentration, Dreissena showed in the present study a higher accumulation of disulfoton than thiometon (Figure 2), which agrees with the three times higher octanol-water partition coefficient of disulfoton (EAWAG 1987). The lower tissue concentration found after demeton-S-methyl exposure could be explained for example with its more than 10 times higher water solubility than that of the parent compound, thiometon.

It could be shown that the highest body burdens were always measured in surviving mussels. As living mussels are active water filters, the total amount of filtered organophosphate-containing water therefore largely depends on the exposure time and the viability of the animal. Furthermore, the results indicate that the body burdens were not primarily lethal to the mollusc. This is corroborated by the 3-times higher disulfoton body burdens of the mussels collected in the Rhine river after the Sandoz incident (Introduction) than the surviving mussels after the acute experiments. The fact that the Rhine mussels had, contrary to the results of this study, much higher disulfoton than thiometon tissue concentrations can be explained by the much higher disulfoton concentrations still present in the Rhine sediments $31 / 2$ months after the incident.

Acknowledgments. This study was supported by a grant from the Swiss Federal Institute of Technology of Zurich (Grant No. 0-20-544-91).

\section{References}

Arnold H, Braunbeck T (1992) Disulfoton as a major toxicant in the river Rhine chemical spill at Basle in 1986: Acute and chronic studies with eel and rainbow trout. EIFAC/XVII/Symp E9

ASTM (1990) Standard guide for conducting acute toxicity tests with fish, macroinvertebrates, and amphibians. In: Annual book of ASTM standards, Volume 11.04. Philadelphia, PA, pp 360-379

Capel PD, Giger W, Reichert P, Wanner O (1988) Accidental input of pesticides into the Rhine river. Environ Sci Technol 22:992-996

De Bruijn J, Hermens J (1991) Uptake and elimination kinetics of organophosphrous pesticides in the guppy (Poecilla reticulata): Correlations with the octanol/water partition coefficient. Environ Toxicol Chem 10:791-804

$D F G$ (1982) Organochlor-und Organophosphor-Pestizide. In: Rückstandsanalytik von Pflanzenschutzmittel. Deutsche Forschungsgemeinschaft. Weinheim, Deerfield Beach Florida, Basel, pp 1-13

EAWAG (1987) Verhalten der Chemikalien im Rhein, biologischer Zustand und Wiederbelebung des Rheins nach dem Brand in Schweizerhalle. Swiss Federal Institute for Water Resources and Water Pollution Control (EAWAG). Dübendorf, Switzerland, Project 4727

Ferrario JB, DeLeon IR, Peuler EA (1994) Bioaccumulation of chemical markers as a means for the field detection and verification of organophosphorus warfare agents. Environ Sci Technol 28: 1893-1897

Frank R, Braun HE, Chapman N, Burchart C (1991) Degradation of parent compounds of nine organophosphorus insecticides in Ontario surface and ground waters under controlled conditions. Bull Environ Contam Toxicol 47:374-380

Gallo MA, Lawryk NJ (1991) Organic phosphorus pesticides. In: Hayes WJ, Hayes ERL (eds) Handbook of pesticide toxicology. Academic Press, Inc., San Diego, CA, pp 917-1090

Güttinger H, Stumm W (1992) An analysis of the Rhine pollution caused by the Sandoz chemical accident, 1986. Interdisciplin Sci Rev 17:127-136

Hall RJ, Kolbe E (1980) Bioconcentration of organophosphorus pesticides to hazardous levels by amphibians. J Toxicol Environ Health 6:853-860

Heyer CB, Kater SB, Karlsson UL (1973) Neuromuscular systems in molluscs. Am Zool 13:247-270 
Johnson MK (1975) The delayed neuropathy caused by some organophosphorus esteres: Mechanisms and challenge. Crc Crit Rev Toxicol 3:289-316

Lotti M (1992) The pathogenesis of organophosphate polyneuropathy. Crc Crit Rev Toxicol 21:465-487

Mahendru VK, Agarwal RA (1983) Phorate and mexacarbate induced changes in enzymes of the snail, Lymnaea acuminata. Arch Environ Contam Toxicol 12:77-82

Mayer FL, Ellersieck MR (1986) Manual of acute toxicity: Interpretation and data base for 410 chemicals and 66 species of freshwater animals. Washington, DC

McLeese DW, Zitko V, Sergeant DB (1979) Uptake and excretion of fenitrothion by clams and mussels. Bull Environ Contam Toxicol 22:800-806

Mercer AL, McGregor DD (1982) Neural regulation and pharmacology of the gut of Chione stutchburyi, a bivalve mollusc. Comp Biochem Physiol 73C:243-251

Miller CW, Zuckerman BM, Charig AJ (1966) Water translocation of diazinon- $\mathrm{C}^{14}$ and parathion- $\mathrm{S}^{35}$ of a model cranberry bog and subsequent occurrence in fish and mussels. Trans Amer Fish Soc 95:345-349

Morton B (1969) Studies on the biology of Dreissena polymorpha Pall. I. General anatomy and morphology. Proc Malac Soc Lond 38:301-321

Nichols SJ (1992) Maintenance of the zebra mussel (Dreissena polymorpha) under laboratory conditions. In: Nalepa TF, Nalepa DS (eds) Zebra mussels: Biology, impacts, and control. Boca Raton, Florida, pp 733-747

Payne JF, Fancey LL, Rahimtula AD, Porter EL (1987) Review and perspective on the use of mixed-function oxygenase enzymes in biological monitoring. Comp Biochem Physiol 86C:233-245

Prozorovskii VB, Skopichev VG (1993) Morphological changes in mouse and rat erythrocytes upon exposure to cholinesterase organophosphorus inhibitors. Bull Exp Biol Med 115:479-481
Rosza K (1984) The pharmacology of molluscan neurons. Prog Neurobiol 23:79-150

Singh AK, Zeleznikar RJ, Drewes LR (1985) Analysis of soman and sarin in blood utilizing a sensitive gas chromatography-mass spectrometry method. J Chromatogr 324:163-172

Suter W (1982) Vergleichende Nahrungsökologie von überwinternden Tauchenten (Bucephala, Aythya) und Bläßhuhn (Fulica atra) am Untersee-Ende/Hochrhein (Bodensee). Ornitholog Beobachter $79: 225-254$

Takase I, Oyama H (1985) Uptake and bioconcentration of disulfoton and its oxidation compounds in carp, Cyprinus carpio L. J Pestic Sci $10: 47-53$

Villar D, Gonzalez M, Gualda MJ, Schaeffer DJ (1994) Effects of organophosphorus insecticides on Duglesia tigrina: Cholinesterase activity and head regeneration. Bull Environ Contam Toxicol 52:319-324

Wanner O, Egli T, Fleischmann T, Lanz K, Reichert P, Schwarzenbach RP (1989) Abbau von Thiometon und Disulfoton im Wasser. Environ Sci Technol Appl 32:1232-1342

Ward TR, Ferris DJ, Tilson HA, Mundy WR (1993) Correlation of the anticholinesterase activity of a series of organophosphates with their ability to compete with agonist binding to muscarinic receptors. Toxicol Appl Pharmacol 122:300-307

Willems JL, De Bisschop HC, Verstraete AG, Declerck C, Christiaens Y, Vanscheeuwyck P, Buylaert WA, Vogelaers D, Colardyn F (1993) Cholinesterase reactivation in organophosphorus poisoned patients depends on the plasma concentrations of the oxime pralidoxime methylsulphate and of the organophosphate. Arch Toxicol 67:79-84

Wisson M, Van Hoek C, Sauer HH (1976) Thiometon. In: Analytical methods for pesticides and plant growth regulators, Vol. VIII. Academic Press, NY, pp 239-248

Yashiki M, Kojima T, Ohtani M, Chikasue F, Miyazaki T (1990) Determination of disulfoton and its metabolites in the body fluids of a Di-syston ${ }^{\circledR}$ intoxication case. Forensic Sci Int 48:145-154 